\title{
RELATIONSHIPS BETWEEN REPRODUCTION PARAMETERS IN DAIRY COWS
}

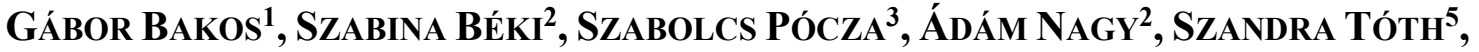 \\ MIKLÓS SZABARI ${ }^{4}$, JóZSEF STEFLER ${ }^{5}$
}

${ }^{1}$ Bos Frucht Agricultural Cooperative 7274 Kazsok, Hungary

${ }^{2}$ Godollo Experimental Farm Ltd. 2173 Kartal, Hungary

${ }^{3}$ UBM Feed Ltd. 2185 Pilisvörösvár, Hungary

${ }^{4}$ AB 2012 Ltd. 7400 Kaposvár, Hungary

${ }^{5}$ Kaposvár University, Faculty of Agriculutral and Enviromental 7400 Kaposvár, Hungary

szabarim@gmail.com

\begin{abstract}
The aim of the reproductive management of dairy farms is to keep low the days in milk (DIM). Milk production can be profitable only in that case. Calvings make only low DIM. From the economic point of view, to evaluate the amount of the calving is not simple because in many cases the insemination and the calving are not in the same year. We wanted to find a reproduction parameter, which is easy to record, available real time, and corrrelate well with other parameters. We collected reproduction data from 21 farms from 2016. Average numbers of cows, number of the ai (artificial insemination) in cows, number of cows pregnancies, open days (OD), service period (SP), time of first ai (TFAI), conception rate of first ai (CRFAI), conception rate of all ai (CRSAI) were collected. The number of the pregnant cows were grouped, pregancies under 120 days after calving -U120- and pregnancies above 200 -A200- days after calving. The economical effect of open days are well-known. OD correlated with the rate of the pregnancies under 120 days after calving $(\mathrm{r}=-0.802 ; \mathrm{P} \leq 0.001)$. The open days correlated with the rate of the pregnancis above 200 days after calving ( $\mathrm{r}=0.889 ; \mathrm{P} \leq 0.001)$. If the rate of $\mathrm{U} 120$ is high, the rate of pregnant cows (ROPC) will be high too $(\mathrm{r}=0.611 ; \mathrm{P}=0.003)$. A200 is in negative relation with ROPC $(\mathrm{r}=-0.525 ; \mathrm{P}=0.015)$. OD correlated with TFAI $(\mathrm{r}=0.562 ; \mathrm{P}=0.008)$. ROPC correlated with TFAI $(\mathrm{r}=-0.457 ; \mathrm{P}=0.037)$. OD correlated with $\mathrm{SP}(\mathrm{r}=$ $0.778 ; \mathrm{P} \leq 0.001)$. SP is in negative correlation with CRFAI and CRSAI $(\mathrm{r}=-0.577, \mathrm{P}=0.006 ; \mathrm{r}=-0.773, \mathrm{P}$ $\leq 0.001)$. SP correlated with U120 and A200 ( $\mathrm{r}=-0.572, \mathrm{P}=0.007 ; \mathrm{r}=0.788 \mathrm{P} \leq 0.001)$. Our study shows that the rate of the pregnant cows are stasistically correlated with many important reproduction parameters. The measurement of the number of pregnant cows is easy, available real time and it has important economical effect on milk production. In summary, the number of pregnant cows is a useful parameter to evaluate the reproductive performance and current status of the farms.
\end{abstract}

Keywords: DIM, number of pregnancies, correlated, reproduction parameters

\section{INTRODUCTION}

Many parameters help to evaluate repdroduction performance. These parameters are connected to the oestrus cycle and the lactation stadium. The calving interval, oped day, conception rate, pregnancy rate, sevice period, calving rate, number of services, sevices per conception, non-return rate, productivity, first sevice conception rate, days to first service (ZÖLDÁG AND HARASZTI, 1994; PLAIZIER ET AL., 1998; KOVÁCS ET AL., 2010; FODOR AND ÓZSVÁRI, 2015) can be used to assess reproduction performance. KRAJNEC ET AL. (2015) evaluate many reproduction parameters.

Milk production can only be profitable with low days in milk (DIM). The aim of the reproductive management is to keep low DIM of dairy farms (RIBERIO ET AL., 2012). In fact, calvings make only low DIM. From the economic point of view, to evaluate the amount of calving is not simple because in many cases the insemination and the calving are not happening in the same year. Previously, open day and calving intervall were used to evaluate reproduction from the ecomonical pont of view (ÓZSVÁRI AND KERÉNYI, 2004). 


\section{MATERIAL AND METHOD}

We collected reproduction data from 21 farms from 2016. All of the farms are located in Hungary. They have different sizes with different milk production levels. They use different reproduction technologies. All of these farms use RISKA farm system. Average numbers of cows, number of the ai (artificial insemination) in cows, number of cows pregnancies, open days (OD), time of first ai (TFAI), conception rate of first ai (CRFAI), conception rate of all ai (CRSAI) were collected for the study purposes. From these data, service period was calculated by our study group (open day - time of first ai $=$ service period). The average number of cows was calculated by RISKA software. The numbers of the pregnant cows were grouped according to the followings: pregnancies under 120 days after calving -U120- and pregnancies above 200 -A200- days after calving. Pregnancies were correlated to the average number of cows (Table 1). Correlation between reproduction parameters were evaluated by SPSS statistical software package.

\section{RESULTS}

In the daily routine, there are some possibilities to create good reproduction parameters in the dairy farms. If only the heating cows are selected (for condition, heating intensity) some parameters predict a well functioning, while the number of pregnant cattles are still low. In our data, there is a farm (farm 18) with relatively decreased OD (124 days) but on the ohter hand, the farm had low rate of pregnant cattles (for example: $62.9 \%$ ). The same phenomena could happen with the CRSAI and CRFAI values (see farm1) (Table 1).

Table 1. Basic data

\begin{tabular}{l|c|c|c|c|c|c|c|c} 
& ROPC & OD & TFAI & SP & CRFAI & CRSAI & U120 & A200 \\
\hline farm1 & 66.6 & 157 & 97 & 60 & 32.7 & 33.2 & 42.0 & 23.7 \\
\hline farm2 & 79.4 & 124 & 66 & 58 & 31.6 & 30.6 & 64.3 & 13.1 \\
\hline farm3 & 78.6 & 129 & 71 & 58 & 30.8 & 30.5 & 59.7 & 13.8 \\
\hline farm4 & 74.8 & 129 & 71 & 58 & 30.3 & 31.8 & 57.9 & 15.6 \\
\hline farm5 & 75.9 & 141 & 68 & 73 & 30.1 & 30.5 & 52.9 & 20.1 \\
\hline farm6 & 72.8 & 121 & 67 & 54 & 29.2 & 28.4 & 62.3 & 12.5 \\
\hline farm7 & 70.7 & 128 & 74 & 54 & 28.1 & 31.1 & 51.9 & 15.9 \\
\hline farm8 & 64.6 & 157 & 89 & 68 & 27.9 & 28.6 & 44.3 & 22.7 \\
\hline farm9 & 58.1 & 129 & 71 & 58 & 26.4 & 30.3 & 54.3 & 17.2 \\
\hline farm10 & 71.9 & 151 & 79 & 72 & 22.8 & 23.0 & 49.4 & 19.5 \\
\hline farm11 & 62.5 & 186 & 85 & 101 & 22.4 & 21.4 & 41.1 & 33.7 \\
\hline farm12 & 72.2 & 153 & 66 & 87 & 21.3 & 23.9 & 48.9 & 23.6 \\
\hline farm13 & 84 & 116 & 50 & 66 & 21.2 & 26.5 & 63.1 & 12.4 \\
\hline farm14 & 72.9 & 163 & 61 & 102 & 21.0 & 20.3 & 48.1 & 26.7 \\
\hline farm15 & 73.6 & 159 & 73 & 86 & 20.6 & 25.3 & 42.8 & 27.9 \\
\hline farm16 & 69.8 & 156 & 62 & 94 & 20.8 & 19.6 & 50.9 & 23.9 \\
\hline farm17 & 72.6 & 126 & 58 & 68 & 18.6 & 22.7 & 59.2 & 14.9 \\
\hline farm18 & 62.9 & 124 & 59 & 65 & 18.0 & 22.8 & 51.4 & 21.0 \\
\hline farm19 & 60.8 & 152 & 73 & 79 & 17.7 & 21.3 & 36.8 & 30.6 \\
\hline farm20 & 72.9 & 147 & 65 & 82 & 15.6 & 20.0 & 41.8 & 28.2 \\
\hline farm21 & 72.4 & 129 & 53 & 76 & 13.8 & 20.7 & 51.2 & 17.6
\end{tabular}


Open days and conception rate are not able to evaluate the reproduction performance well. The economical effect of open days are well-known. The change of open days with any number of days has significant economical effect. OD correlated with the rate of the pregnancies under 120 days after calving $(\mathrm{r}=-0.802 ; \mathrm{P} \leq 0.001)$ (Table 2).

Table 2. Correlation between OD and U120 and A200

\begin{tabular}{|ll|r|r|r|}
\hline & & OD & U120 & \multicolumn{1}{c|}{ A200 } \\
\hline OD & Correlation & 1 & $-.802^{* *}$ & $.889^{* *}$ \\
& Sig. (2-tailed) & &, 000 &, 000 \\
& $\mathrm{~N}$ & 21 & 21 & 21 \\
\hline U120 & Correlation & $-.802^{* *}$ & 1 & $-.920^{* *}$ \\
& Sig. (2-tailed) & .000 & & .000 \\
& $\mathrm{~N}$ & 21 & 21 & 21 \\
\hline A200 & Correlation & $.889^{* *}$ & $-.920^{* *}$ & 1 \\
& Sig. (2-tailed) & .000 & .000 & \\
& $\mathrm{~N}$ & 21 & 21 & 21 \\
\hline
\end{tabular}

The open days correlated with the rate of the pregnancies above 200 days after calving $(\mathrm{r}=$ $0.889 ; \mathrm{P} \leq 0.001)$.

If the rate of U120 is elevated, the rate of pregnant cows (ROPC) will be increased too $(\mathrm{r}=$ $0.611 ; \mathrm{P}=0.003)$ (Table 3).

Table 3. Correlation between U120 and ROPC and A200

\begin{tabular}{|ll|r|r|r|}
\hline & \multicolumn{1}{|c|}{ U120 } & A200 & ROPC \\
\hline U120 & Correlation & 1 & $-.920^{* *}$ & $.611^{* *}$ \\
& Sig. (2-tailed) & & .000 & .003 \\
$\mathrm{~N}$ & 21 & 21 & 21 \\
\hline A200 & Correlation & $-.920^{* *}$ & 1 & $-.525^{*}$ \\
& Sig. (2-tailed) & .000 & & .015 \\
& $\mathrm{~N}$ & 21 & 21 & 21 \\
\hline ROPC & Correlation & $.611^{* *}$ & $-.525^{*}$ & 1 \\
& Sig. (2-tailed) & .003 & .015 & \\
N & 21 & 21 & 21 \\
\hline
\end{tabular}

A200 is in negative relation with ROPC $(r=-0.525 ; \mathrm{P}=0.015)$. If there are many pregnant cows in the farm, the number of pregnant cows above 200 days from calving is decreased. OD correlated with TFAI $(\mathrm{r}=0.562 ; \mathrm{P}=0.008)($ Table 4). 
Table 4. Correlation between OP and TFAI

\begin{tabular}{|rl|r|r|}
\hline & & \multicolumn{1}{|c|}{ OD } & \multicolumn{1}{c|}{ TFAI } \\
\hline OD & Correlation & 1 & $.562^{* *}$ \\
& Sig. (2-tailed) & & .008 \\
$\mathrm{~N}$ & 21 & 21 \\
\hline TFAI & Correlation & $.562^{* *}$ & 1 \\
& Sig. (2-tailed) & .008 & \\
$\mathrm{~N}$ & 21 & 21 \\
\hline
\end{tabular}

** Correlation is significant at the 0.01 level (2-tailed).

To achieve low OD, the AI should be as close as possible to the calving period. ROPC correlated with TFAI $(\mathrm{r}=-0.457 ; \mathrm{P}=0.037)($ Table 5$)$.

Table. 5 Correlation between TFAI and ROPC

\begin{tabular}{|rl|r|r|}
\hline & \multicolumn{1}{|c|}{ TFAI } & ROPC \\
\hline TFAI Correlation & 1 & $-.457^{*}$ \\
& Sig. (2-tailed) & & .037 \\
$\mathrm{~N}$ & 21 & 21 \\
\hline ROPC Correlation & $-.457^{*}$ & 1 \\
& Sig. (2-tailed) & .037 & \\
$\mathrm{~N}$ & 21 & 21 \\
\hline
\end{tabular}

* Correlation is significant at the 0.05 level (2-tailed).

To achieve a higher number of pregnant cows, the first AI should be started as soon as possible. OD correlated with $\mathrm{SP}(\mathrm{r}=0.778 ; \mathrm{P} \leq 0.001)$ (Table 6).

Table 6. Correlation between SP and OD

\begin{tabular}{|rl|r|r|}
\hline & & \multicolumn{1}{|c|}{ SP } & \multicolumn{1}{c|}{ OD } \\
\hline SP & Correlation & 1 & $.778^{* *}$ \\
& Sig. (2-tailed) & & .000 \\
& $\mathrm{~N}$ & 21 & 21 \\
\hline OD & Correlation & $.778^{* *}$ & 1 \\
& Sig. (2-tailed) & .000 & \\
& $\mathrm{~N}$ & 21 & 21 \\
\hline
\end{tabular}

** Correlation is significant at the 0.01 level (2-tailed).

The low SP means that, the cattle become pregnant in a very short period of time. SP is in negative correlation with CRFAI and CRSAI $(\mathrm{r}=-0.577, \mathrm{P}=0.006 ; \mathrm{r}=-0.773, \mathrm{P} \leq 0.001)$ (Table 7). 
Table 7. Correlation between SP and CRFAI and CRSAI

\begin{tabular}{|ll|r|r|r|}
\hline & & \multicolumn{1}{|c|}{ SP } & CRFAI & CRSAI \\
\hline SP & Correlation & 1 & $-.577^{* *}$ & $-.773^{* *}$ \\
& Sig. (2-tailed) & & .006 & .000 \\
$\mathrm{~N}$ & 21 & 21 & 21 \\
\hline CRFAI & Correlation & $-.577^{* *}$ & 1 & $.903^{* *}$ \\
& Sig. (2-tailed) &, 006 & &, 000 \\
$\mathrm{~N}$ & 21 & 21 & 21 \\
\hline CRSAI & Correlation & $-.773^{* *}$ & $.903^{* *}$ & 1 \\
& Sig. (2-tailed) & .000 & .000 & \\
$\mathrm{~N}$ & 21 & 21 & 21 \\
\hline
\end{tabular}

** Correlation is significant at the 0.01 level (2-tailed).

The SP can only be short if the conception rate is favourable. SP correlated with U120 and A200 $(r=-0.572, \mathrm{P}=0.007 ; \mathrm{r}=0.788 \mathrm{P} \leq 0.001)($ Table 8).

Table 8. Correlation SP and U120 and A200

\begin{tabular}{|ll|r|r|r|}
\hline & & \multicolumn{1}{|c|}{ SP } & \multicolumn{1}{c|}{ U120 } & \multicolumn{1}{c|}{ A200 } \\
\hline SP & Correlation & 1 & $-.572^{* *}$ & $.788^{* *}$ \\
& Sig. (2-tailed) & & .007 & .000 \\
& $\mathrm{~N}$ & 21 & 21 & 21 \\
\hline U120 & Correlation & $-.572^{* *}$ & 1 & $-.920^{* *}$ \\
& Sig. (2-tailed) & .007 & & .000 \\
& $\mathrm{~N}$ & 21 & 21 & 21 \\
\hline A200 & Correlation & $.788^{* *}$ & $-.920^{* *}$ & 1 \\
& Sig. (2-tailed) & .000 & .000 & \\
$\mathrm{~N}$ & 21 & 21 & 21 \\
\hline
\end{tabular}

** Correlation is significant at the 0.01 level (2-tailed).

There are many pregnant cows under 120 days from calving when the SP is low.

\section{CONCLUSIONS}

Our study shows that the rate of the pregnant cows are statistically correlated with many important reproduction parameters. The measurement of the number of pregnant cows is simple, available real time and it has important economical effect on milk production (correlation open days). In summary, the number of pregnant cows is a potentially useful parameter to evaluate the reproductive performance and current status of the farms.

\section{ACKNOWLEDGEMENTS}

We are thankful for the Management of the farms and Margit Szabari MD PhD from Harvard Medial School, Massachusetts General Hospital for their help. 


\section{REFERENCES}

HARASZTI, J., ZÖLDÁG, L. (1994): Háziállatok szülészete és szaporodásbiológiája Mezőgazda Kiadó, Budapest.

KovÁCS, A.Z., Stefler, J., SzABARI, M. (2010): Szaporodásbiológiai mutatók egységes értelmezése a tejelőmarha-tenyésztésben. Állattenyésztők Lapja 38(2): 8-9.

KrajneC, F., FOdOR, I., FÖLDI, J., ÓzSVÁRI, L. (2016): Tehenészetek szaporodási teljesítményének összehasonlító értékelése egységesített mutatók alapján. Magyar Állatorvosok Lapja 138: 451-462.

ÓZSVÁRI, L., KERÉNYI, J. (2004): A szaporodásbiológiai zavarok által okozott gazdasági veszteségek számszerüsítése egy nagyüzemi holstein-fríz tehenészetben. Magyar Állatorvosok Lapja 126: 523-531.

Plaizier, J.C.B., Lissemore, K.D., Kelton, D., King, G.J. (1998): Evaluation of overall reproductive performance of dairy herds. Journal of Dairy Sci. 81(7): 1848-1854.

Ribiero, E.S., GAlvaO, K.N., Thatcher, W.W., SANTOS, J.E.P. (2012): Economic aspects of applying reproductive technologies to dairy herds. Anim Reprod. 9(3): 370-387. 